\title{
Estimation of Combining Ability Effect in Mungbean (Vigna radiata (L.) Wilczek)
}

\author{
S.S. Kakde*, A.B. Gawate and S.V. Mandge \\ College of Agriculture, Kharpudi, Jalna, Vasantrao Naik Marathwada, Krishi Vidyapeeth, \\ Parbhani- 431 402, Maharashtra, India \\ *Corresponding author
}

\section{A B S T R A C T}

\begin{abstract}
The present investigation entitled "Estimation of combining ability effect in mungbean (Vigna radiata (L.) Wilczek) was carried out at College of Agricultural, Kharpudi, during kharif 2016 and 2017. The material for the present investigation comprised ten parents BPMR 182, BPMR 132, BPMR 21, BPMR 126, BPMR 75 and BPMR 38. Four varieties as females are BM 2002-1, BM 4, JL 781 and AKM 4. Were crossed in Line x Tester fashion to estimate the combining ability for yield and yield attributing traits in mungbean. Analysis of variance revealed significant differences among genotypes, crosses, lines, testers and line $\mathrm{x}$ tester interactions for most of the traits. Preponderance of non-additive gene effects was realized from higher values of specific combining ability compared to general combining ability and ratio of variances of SCA to GCA. The parents showed high GCA can be used for the future hybridization programmes. The gca estimates of lines and testers emphasized the importance of lines BM 2002-1, JL 781 and tester BPMR 126, BPMR 75 for their use as a desirable parents for enhancing the yield potential through assembling the favorable genes for yield and yield components. The crosses which showed high SCA effect could be used for the hybrid development. The high yielding crosses viz., BM 2002-1 X BPMR 126, BM 2002-1 X BPMR 75, BM 4 X BPMR 75, JL 781 X BPMR 132, JL 781 X BPMR 126 and JL 781 X BPMR 75 were found to be the superior for seed yield and yield component and should be further tested across the different environment for their stability performance.
\end{abstract}

\begin{tabular}{|c|}
\hline Keywords \\
\hline $\begin{array}{l}\text { SCA, GCA and } \\
\text { Mungbean }\end{array}$ \\
\hline Article Info \\
\hline $\begin{array}{l}\text { Accepted: } \\
\text { 12 January } 2019 \\
\text { Available Online: } \\
\text { 10 February } 2019\end{array}$ \\
\hline
\end{tabular}

\section{Introduction}

Mungbean (vigna radiate (L.) Wilczek) is a self pollinated legume originated in south Asia. The word legume is derived from the word 'large' which means 'to gather' or picked by hands, as distinct form reaping the cereal crops. It is an economically important crop in India, Pakistatn, Thialand, Vieatnam, Myanmor and China.

Mungbean also known as green gram, it is short duration grain legume with wider adoptability. Mungbean is considered to be originated from Vigna sablobata. The origin of mungbean is supposed to be India 
(Vavilov, 1926 and Zukoveshij, 1962). In India it is one of the most important crops grown on large area. In Maharashtra it ranks second in kharif crop grown after Pigeonpea with area 4.30 lakh hector (ha) with production of 2.07 lakh tonnes with productivity $483 \mathrm{~kg} / \mathrm{ha}$ (Chief statistician Commisionorate of Agriculture Report 201314, Pune). It is mainly used in making Dal, snacks, curries and soup. The germinated seeds have more nutritional value compared with Asparagus or Mushroom. The food value of mungbean lies in its high and easily digestible protein. The mungbean seeds contain approximately $25-28 \%$ protein on dry weight basis.

Mung bean is important source of dietary protein in all over the world but in major in Asia, Africa and Latin America. The protein content and amino acids of the protein and its digestibility determines the food value of mungbean (Casey and Wriniey, 1982). It is used in multiple cropping systems with cereals, groundnut, sugarcane and other crops, following an important component of crop rotation.

Mungbean has established itself as a highly valuable short duration grain legume crop having many desirable characteristics like wider adaptability, low input requirement and ability to improve the soil fertility by fixing atmospheric nitrogen with the help of symbiotic bacteria, Rhizobium present in root nodules. Mungbean has been recognized as a very suitable crop for mixed, inter and multiple- cropping systems as well as for various crop rotations.

Combining ability studies utilizing line $\mathrm{x}$ tester analysis provides information in this direction particularly for initial screening of large number of genotype for combining ability. Study of general combining ability (gca) effects helps in selection of superior parents and specific combining ability (sca) effects for superior hybrids.

\section{Materials and Methods}

The parent for experiment included six genotypes of mungbean (Vigna radiate $\mathrm{L}$. Wilczek) as males (Tester) BPMR 182, BPMR 132, BPMR 21, BPMR 126, BPMR 75 and BPMR 38. Four varieties as females are BM 2002-1, BM 4, JL 781 and AKM 4. Each female were crossed with six selected male genotypes in $\mathrm{L} \mathrm{X} \mathrm{T} \mathrm{mating} \mathrm{system} \mathrm{at}$ College of Agriculture, Kharpudi, Jalna, Maharastra. All the genotypes (Ten parent and 24 F1, s) were evaluated in Randomized Block Design with two replication during khrif, 2017. Each genotype was grown in one row of three meter length with a spacing of $45 \mathrm{~cm}$ between row and $10 \mathrm{~cm}$ between plants. Recommended agronomic and plant protection package of practice were followed to raise healthy crop. Data were recorded on five randomly selected competitive plants in each genotype and replication. Mean value on per plant basis were recorded for the characters, viz., Days to $50 \%$ flowering, Days to maturity, Plant height $(\mathrm{cm})$, Number of clusters per plant, Number of pods per cluster, Number of pods per plants, Number of seeds per pod, Pod length $(\mathrm{cm}), 100$ seed weight (g), Seed yield per plant (g), Protein (\%). The protein percentage was estimated by microkjeldahl method.

\section{Results and Discussion}

Analysis of variance along with the estimates of gca and sca variance their ratio for eleven character is shown in Table 1. The annova showed highly significant differences for majority of character, this indicates the presence of sufficient variability in experimental material. The variance due to crosses was highly significant for all the characters except hundred seed weight, which 
indicated the diverse nature of selected parent for majority of the character. The mean square due to line showed highly significant differences for plant height, pod length, 100 seed weight and seed yield per plant which indicated the presence of sufficient variability for these four characters. Significant variance is due to tester for seed yield per plant. The significant variance due to line $\mathrm{x}$ tester interaction for all the traits except that of 100 seed weight, showed its existence among the tester and hybrid population respectively for these eleven traits. This indicated the presence of significant differences between males and females.

Based on the study per se performance of parents and estimates of gca effect Among female parents, BM 2002-1was found to be a good combiner and exhibited significant GCA effects for all the traits excepting number of number of cluster per plant and protein percentage. BM 4 and AKM 4 was good general combiner for $50 \%$ flowering and days to maturity, while JL 781exhibit significant GCA effect for days to $50 \%$ flowering, days to maturity, plant height, number of pods per plant, pod length and seed yield per plant.

Out of six males or tester, BPMR 126 was a good general combiner for days to $50 \%$ flowering, days to maturity, number of pods per plant, pod length, seed yield and protein percent followed by BPMR 75 was exhibit significant high GCA effect for days to $50 \%$ flowering, days to maturity, number of cluster per plant, number of pods per plant, number of seeds per pods, pod length, seed yield per plant and protein percent, whereas tester AKM 4 exhibited significant GCA effect for days to $50 \%$ flowering, days to maturity and number of pods per plant (Table 2). Similar results were reported by Jahagirdar (2001), Aher et al., (1999), Singh (2005), Barad et al., (2008), Patil et al., (2011) and Surashe et al., (2017).
The cross combination JL 781 XBPMR 132(1.838) recorded highest significant desirable SCA effect for seed yield per plant. Similar result has also been reported by Barad et al., (2008), Patil et al., (2011).

The cross combination JL 781 XBPMR 126 (3.754) recorded highest significant desirable SCA effect for number of pods per plant. This result is in agreement with the finding of Ahuja (1980), Shanthipriya et al., (2012).

The highest significant negative desirable SCA effect was observed for days to maturity in BM 4 X BPMR 132(-3.163) similar results were also reported by Jahagirdar (2001).

For plant height in BM $4 \times$ BPMR 132 (3.954) was observed highest significant desirable SCA effect. This result was in agreement with the findings of Manjare (1976), Shanthipriya et al., (2012)

The cross combination BM 2002-1 x BPMR38 (1.050) had recorded highest significant desirable SCA effect for number of clusters per plant. Similar results were also reported by Manjare (1976), Shanthipriya et al., (2012).

For number of pods per cluster in JL $781 \mathrm{x}$ BPMR 132 (0.492) was revealed highest significant desirable SCA effect. This result was in agreement with the finding of Shanthipriya et al., (2012).

The cross combination AKM 4 x BPMR 132 (0.467) observed highest significant desirable SCA effect for number of seed per pod. These results are in confirmation with the previous work done by Jahagirdar (2001), and Singh and Dikshit (2003).

The hybrid combination BM 4 x BPMR 75 (1.826) recorded highest significant desirable SCA effect for pod length (Table 3). 
Table.1 Analysis of variance of line X tester with respect to eleven characters in greengram (Vigna radiata (L.) Wilczek)

\begin{tabular}{|c|c|c|c|c|c|c|c|c|c|c|c|c|}
\hline $\begin{array}{c}\text { Sorce of } \\
\text { variability }\end{array}$ & d.f. & $\begin{array}{c}\text { Days to } \\
50 \% \\
\text { flowering }\end{array}$ & $\begin{array}{l}\text { Days to } \\
\text { maturity }\end{array}$ & $\begin{array}{l}\text { Plant height } \\
\text { (cm) }\end{array}$ & $\begin{array}{c}\text { No. of } \\
\text { clusters } \\
\text { per plant }\end{array}$ & $\begin{array}{l}\text { No. of pods } \\
\text { per cluster }\end{array}$ & $\begin{array}{c}\text { No. of pods } \\
\text { per plant }\end{array}$ & $\begin{array}{c}\text { No. of } \\
\text { seeds per } \\
\quad \text { pod }\end{array}$ & $\begin{array}{l}\text { Pod length } \\
\quad(\mathrm{cm})\end{array}$ & $\begin{array}{c}\text { 100- seed } \\
\text { weight } \\
\text { (gm) }\end{array}$ & $\begin{array}{l}\text { Seed yield } \\
\text { per plant } \\
\quad(\mathrm{gm})\end{array}$ & $\begin{array}{l}\text { Protein } \\
\text { per cent }\end{array}$ \\
\hline Replication & 1 & 2.167 & 2.340 & 0.056 & 1.401 & 0.053 & 3.967 & 0.030 & 0.750 & 0.004 & 1.512 & 0.122 \\
\hline Crosses & 23 & $5.724 * *$ & $9.568 * *$ & $13.086 * *$ & $15.261 * *$ & $0.267 * *$ & $14.830 * *$ & $0.376 * *$ & $3.204 * *$ & 0.196 & $3.011 * *$ & $0.999 * *$ \\
\hline Lines & 3 & 6.614 & 17.314 & $32.189 *$ & 29.383 & 0.517 & 3.816 & 0.778 & $10.918 * *$ & $0.738 * *$ & $5.187 *$ & 0.120 \\
\hline Testers & 5 & 9.466 & 15.624 & 15.666 & 22.818 & 0.289 & 26.133 & 0.536 & 2.545 & 0.057 & $7.664 * *$ & 1.835 \\
\hline $\begin{array}{l}\text { Females X } \\
\text { Males (L X T) }\end{array}$ & 15 & $4.298 * *$ & $6.000 * *$ & $8.406 * *$ & $9.917 * *$ & $0.209 * *$ & $13.265 * *$ & $0.242 * *$ & $1.881 * *$ & 0.134 & $1.025 *$ & $0.896 * *$ \\
\hline Error & 23 & 1.010 & 1.168 & 0.858 & 1.117 & 0.053 & 1.177 & 0.045 & 0.336 & 0.105 & 0.345 & 0.177 \\
\hline
\end{tabular}

Table.2 Estimation of general combining ability with respect to eleven characters in greengram (Vigna radiate L. Wilczek)

\begin{tabular}{|c|c|c|c|c|c|c|c|c|c|c|c|}
\hline Genotypes & $\begin{array}{c}\text { Days to } \\
50 \% \\
\text { flowering }\end{array}$ & $\begin{array}{l}\text { Days to } \\
\text { maturity }\end{array}$ & $\begin{array}{c}\text { Plant } \\
\text { height }\end{array}$ & $\begin{array}{c}\text { No. of } \\
\text { clusters } \\
\text { per plant }\end{array}$ & $\begin{array}{l}\text { No. of } \\
\text { pods per } \\
\text { cluster }\end{array}$ & $\begin{array}{c}\text { No. of } \\
\text { pods per } \\
\text { plant }\end{array}$ & $\begin{array}{l}\text { No. of } \\
\text { seeds per } \\
\text { pod }\end{array}$ & Pod length & $\begin{array}{l}100 \text { seed } \\
\text { weight }\end{array}$ & $\begin{array}{c}\text { Seed yield } \\
\text { per plant }\end{array}$ & $\begin{array}{l}\text { Protein } \\
\text { per cent }\end{array}$ \\
\hline \multicolumn{12}{|l|}{ Testers } \\
\hline BPMR 182 & -0.304 & -0.454 & 0.329 & $-0.292 * *$ & $-0.292 * *$ & -0.363 & -0.125 & -0.103 & -0.049 & -0.750 & 0.102 \\
\hline BPMR 132 & $1.196 * *$ & $2.296 * *$ & $-0.821 *$ & $-0.192 * *$ & -0.042 & -0.562 & -0.100 & -0.303 & -0.041 & $-0.627 * *$ & $-0.673 * *$ \\
\hline BPMR 21 & -0.004 & -0.554 & $1.979 * *$ & 0.183 & 0.033 & $1.263 * *$ & $0.275 * *$ & $0.629 * *$ & 0.001 & -0.240 & $0.706^{* *}$ \\
\hline BPMR 126 & $-1.429 * *$ & $-1.579 * *$ & 0.454 & 0.008 & -0.092 & $1.815^{* *}$ & -0.075 & $0.567 * *$ & 0.131 & $1.183 * *$ & $0.667 * *$ \\
\hline BPMR 75 & $-0.779 *$ & $-0.704 *$ & 0.254 & 0.058 & $0.258 * *$ & $2.963 * *$ & $0.350 * *$ & $0.772 * *$ & 0.061 & $1.285^{* *}$ & $0.417 * *$ \\
\hline BPMR 38 & $1.321 * *$ & $0.996 * *$ & $-2.196 * *$ & $0.233 * *$ & 0.133 & $-2.563 * *$ & $-0.325 * *$ & $-0.728 * *$ & -0.104 & $-0.852 * *$ & 0.245 \\
\hline S.E \pm & 0.3395 & 0.3350 & 0.3024 & 0.0680 & 0.0789 & 0.3694 & 0.0759 & 0.1853 & 0.0794 & 0.2173 & 0.127 \\
\hline C.D. at $5 \%$ & 0.7023 & 0.6929 & 0.6256 & 0.1406 & 0.1633 & 0.7642 & 0.1571 & 0.3833 & 0.1642 & 0.3670 & 0.264 \\
\hline C.D. at $1 \%$ & 0.9531 & 0.9403 & 0.8489 & 0.1908 & 0.2216 & 1.0371 & 0.2131 & 0.5202 & 0.222 & 0.4981 & 0.359 \\
\hline \multicolumn{12}{|l|}{ Lines } \\
\hline BM 2002-1 & $-0.529 *$ & -0.746 & $1.004 * *$ & 0.075 & $0.217 * *$ & $1.229 * *$ & $0.342 * *$ & $1.105^{* *}$ & $0.285^{* *}$ & $0.902 * *$ & 0.123 \\
\hline BM 4 & -0.188 & $-1.088 * *$ & $-1.879 * *$ & -0.058 & 0.033 & -0.463 & $-0.275^{* *}$ & 0.078 & $-0.288 * *$ & $-0.465^{*}$ & -0.095 \\
\hline JL 781 & $-0.629 *$ & $-1.296 *$ & $1.688 * *$ & -0.092 & 0.033 & $0.821 * *$ & -0.025 & $1.106 * *$ & 0.102 & $0.654 * *$ & 0.039 \\
\hline AKM 4 & $-0.971 * *$ & $-0.954 * *$ & $-0.812 * *$ & 0.075 & $-0.283 * *$ & $1.154 * *$ & -0.042 & $-1.212 * *$ & -0.100 & 0.167 & -0.066 \\
\hline S.E \pm & 0.2772 & 0.273 & 0.2469 & 0.055 & 0.0644 & 0.3016 & 0.062 & 0.1513 & 0.0972 & 0.1774 & 0.104 \\
\hline C.D. at $5 \%$ & 0.5735 & 0.5657 & 0.5108 & 0.1148 & 0.1333 & 0.6240 & 0.128 & 0.3130 & 0.2011 & 0.3670 & 0.216 \\
\hline C.D. at $1 \%$ & 0.7782 & 0.7678 & 0.6931 & 0.1558 & 0.1809 & 0.8468 & 0.174 & 0.4247 & 0.2729 & 0.4981 & 0.293 \\
\hline
\end{tabular}

$*$ and $* *$ indicates significance at 5 and 1 per cent level respective 
Table.3 Estimation of specific combining ability with respect to eleven characters

\begin{tabular}{|c|c|c|c|c|c|c|c|c|c|c|c|c|}
\hline $\begin{array}{l}\text { Sr. } \\
\text { No. }\end{array}$ & Parents/crosses & $\begin{array}{l}\text { Days to } 50 \% \\
\text { flowering }\end{array}$ & $\begin{array}{l}\text { Days to } \\
\text { maturity }\end{array}$ & $\begin{array}{l}\text { Plant } \\
\text { height }\end{array}$ & $\begin{array}{c}\text { No. of } \\
\text { cluster/ plant }\end{array}$ & $\begin{array}{l}\text { No. of pods/ } \\
\text { cluster }\end{array}$ & $\begin{array}{c}\text { No. of pods/ } \\
\text { plant }\end{array}$ & $\begin{array}{c}\text { No. of } \\
\text { seed/ pod }\end{array}$ & $\begin{array}{c}100 \text { seed } \\
\text { weight }\end{array}$ & Pod length & Yield & Protein \% \\
\hline 1 & BM 2002-1 X BPMR 182 & -1.029 & $-1.764^{*}$ & -0.979 & $-0.825 * *$ & 0.058 & -1.338 & $0.408 *$ & 0.157 & 0.020 & 0.670 & -0.055 \\
\hline 2 & BM 2002-1 X BPMR 132 & 0.471 & $1.504 *$ & -0.229 & 0.075 & $-0.492 * *$ & $-1.938 *$ & -0.017 & -0.250 & -0.180 & $-1.115^{*}$ & 0.170 \\
\hline 3 & BM 2002-1 X BPMR 21 & -0.329 & -0.946 & -0.029 & -0.100 & -0.167 & 0.487 & -0.092 & -0.043 & -0.480 & -0.755 & -0.004 \\
\hline 4 & BM 2002-1 X BPMR 126 & $-1.738 * *$ & $-1.421 *$ & -0.204 & -0.225 & -0.042 & $3.188 * *$ & $0.342 *$ & -0.273 & 0.250 & $1.195 *$ & -0.065 \\
\hline 5 & BM 2002-1X BPMR 75 & $-1.463^{*}$ & -0.192 & 0.296 & 0.025 & 0.208 & $1.896^{*}$ & 0.167 & 0.247 & 0.345 & $1.165^{*}$ & 0.033 \\
\hline 6 & BM 2002-1 X BPMR 38 & 1.346 & $2.304 * *$ & 1.146 & $1.050 * *$ & $0.433 *$ & 0.063 & 0.208 & 0.162 & 0.045 & 0.170 & -0.078 \\
\hline 7 & BM 4 X BPMR 182 & 0.688 & 0.588 & 0.004 & $0.408 * *$ & 0.142 & -0.688 & -0.075 & 0.260 & 0.003 & -0.338 & -0.407 \\
\hline 8 & BM 4 X BPMR 132 & $-1.813^{*}$ & $-3.163 * *$ & $3.954 * *$ & $0.408 * *$ & 0.192 & 0.913 & $-0.500 * *$ & 0.353 & 0.603 & 0.077 & $-0.957 * *$ \\
\hline 9 & BM 4 X BPMR 21 & 0.587 & 1.087 & $-1.746^{* *}$ & $-0.367 *$ & 0.317 & $1.738^{*}$ & -0.275 & -0.320 & -0.697 & -0.733 & $0.544 *$ \\
\hline 10 & BM 4 X BPMR 126 & $2.313^{*}$ & $2.713 * *$ & -0.021 & 0.208 & -0.258 & $-2.563 * *$ & 0.275 & 0.170 & -0.267 & -0.833 & 0.378 \\
\hline 11 & BM 4 X BPMR 75 & $-1.438 *$ & $-1.258^{*}$ & $-2.421 * *$ & -0.242 & -0.208 & $1.638^{*}$ & $0.450 * *$ & -0.380 & $1.826 * *$ & $1.347 * *$ & -0.038 \\
\hline 12 & BM 4 X BPMR 38 & -0.337 & $-2.063 * *$ & 0.229 & $-0.417 * *$ & -0.183 & 0.713 & 0.125 & -0.085 & 0.228 & 0.482 & 0.480 \\
\hline 13 & JL 781 X BPMR 182 & -1.129 & -0.296 & $2.938 * *$ & $0.742 * *$ & -0.258 & -0.171 & $-0.425 *$ & -0.260 & $-1.460 * *$ & -0.377 & -0.431 \\
\hline 14 & JL 781 X BPMR 132 & $-2.371 *$ & $-1.454 *$ & $-3.113 * *$ & $-0.758 * *$ & $0.492 * *$ & $1.588^{*}$ & 0.050 & -0.037 & $1.460 * *$ & $1.838 * *$ & 0.334 \\
\hline 15 & JL 781 X BPMR 21 & 0.571 & -0.696 & 0.587 & 0.267 & $-0.383 *$ & $-1.846^{*}$ & 0.275 & 0.050 & $1.040^{*}$ & $1.308 * *$ & 0.510 \\
\hline 16 & JL 781 X BPMR 126 & $-1.367 * *$ & -0.671 & $-1.388^{*}$ & -0.158 & 0.242 & $3.754^{*}$ & 0.025 & 0.230 & $0.850^{*}$ & $1.392 * *$ & $0.664 *$ \\
\hline 17 & JL 781 X BPMR 75 & -1.054 & -0.546 & $2.313 * *$ & $0.392 * *$ & 0.192 & $2.004^{*}$ & 0.200 & 0.090 & $0.865^{*}$ & $1.442 * *$ & -0.503 \\
\hline 18 & JL 781 X BPMR 38 & -0.754 & 0.754 & $-1.337 *$ & $-0.483 * *$ & -0.283 & $-3.771 * *$ & -0.125 & -0.075 & 0.165 & $-0.937 *$ & $0.574 *$ \\
\hline 19 & AKM 4 X BPMR 182 & $1.471 *$ & $1.454^{*}$ & $-1.963 * *$ & $-0.325 *$ & 0.058 & $2.196^{*}$ & 0.092 & -0.158 & $1.437 * *$ & 0.045 & $0.894 * *$ \\
\hline 20 & AKM 4 X BPMR 132 & -1.029 & 0.204 & -0.612 & 0.275 & -0.192 & 0.996 & $0.467 * *$ & -0.065 & $1.037 *$ & -0.800 & 0.454 \\
\hline 21 & AKM 4 X BPMR 21 & -0.829 & 0.554 & 1.188 & 0.200 & 0.233 & -0.376 & 0.092 & 0.312 & 0.137 & 0.180 & $-1.050 * *$ \\
\hline 22 & AKM 4 X BPMR 126 & -1.4 .4 & -0.921 & $1.613^{*}$ & 0.175 & 0.058 & $-4.379 * *$ & 0.042 & -0.128 & $-0.833^{*}$ & 0.030 & $-0.976 * *$ \\
\hline 23 & AKM 4 X BPMR 75 & -0.129 & -0.296 & -0.187 & -0.175 & -0.192 & -1.429 & $-0.483 * *$ & 0.042 & $-1.338^{*}$ & 0.260 & 0.508 \\
\hline 24 & AKM 4 X BPMR 38 & $1.871 *$ & -0.996 & -0.038 & -0.150 & 0.033 & $2.996 * *$ & -0.208 & -0.003 & -0.438 & 0.285 & -0.171 \\
\hline
\end{tabular}

$*$ and $* *$ indicates significance at 5 and 1 per cent level respective 
Similar result has also been reported by Yadav and Lavanya Roopa (2011). In case of protein per cent the cross combination AKM 4 X BPMR 182 (0.894) observed highest significant desirable SCA effect. These results are with confirmation with the result of Shanthipriya et al., (2012).

The parents showed high GCA can be used for the future hybridization programmes. The gca estimates of lines and testers emphasized the importance of lines BM 2002-1, JL 781 and tester BPMR 126, BPMR 75for their use as a desirable parents for enhancing the yield potential through assembling the favourable genes for yield and yield components.

The crosses which showed high SCA effect could be used for the hybrid development. The high yielding crosses viz., BM 2002-1 X BPMR 126, BM 2002-1 X BPMR 75, BM 4 X BPMR 75, JL 781 X BPMR 132, JL 781 X BPMR 126 and JL 781 X BPMR 75were found to be the superior for seed yield and yield component and should be further tested across the different environment for their stability performance.

BPMR 75 was best combiner for seed yield per plant and other some character like number of pod per plant, number of seeds per pod and pod length, whereas, BPMR 38, number of cluster per plant, pod length and BM 2002-1 for days to 50\% flowering, days to maturity, number of pods per cluster and number of seeds per pod and JL 781, days to $50 \%$ flowering, days to maturity, number of pods per plant, pod length. Since high gca effect are due to additive and additive $\mathrm{x}$ additive gene action they can be readily exploited in breeding program (Griffing, 1956).

\section{References}

Aher, R. P., Datur D. V. and Sonawane, Y. P., 1999. Combining ability in mungbean.
Crop Res., 18:256-260.

Ahuja, S. L. 1980. Diallel analysis in F2 generation of mungbean, Thesis Abstract (NAU- Hissar). 6(2): 110-111.

Barad, H. R., Pithia, M. S. and Vachhani, J. H. 2008. Heterosis and combining ability studies for economic traits in mungbean (Vigna radiate (L.) Wilczek). Legume Res., 31.

Griffing, B. 1956. Concept of general and specific combining ability in relation to diallel crossing system. Australian J. Biol. Sci, 9:484-493.

Jahagirdar, J. E. 2001. Heterosis and combining ability studies for seed yield and yield components in mungbean. Indian j. pulses Res., 14(2): 141-142.

Katiyar, M and Amit Kumar. 2015. Genetics Analysis of yield and its component Traits in Mungbean (Vigna radiataL. Wilczek). Int. J. Innovative Res. Dev., 4 (2): 119-121.

Kempthorne, O. 1957. An introduction to genetical statistics. John Wiley and Sons, New York.

Khattak, G.S.S., Haq, M.A., Ashraf, M. and Srinives P., 2001. Combining ability in mungbean (Vigna radiata $(L)$ Wilczek) I. Agronomic traits. Korean J. Crop Sci., 46(5): 420-423.

Manjare, M. R. 1976. Studies on heterosis and combining ability in $8 \times 8$ diallel cross of mungbean. M. Sc. (Agri.). Thesis Mahatma Phule Krishi Vidyapeeth, Rahuri.

Panse, V.G. and Sukhatme, P. V. 1967. Statistical methods for agricultural work. Indian council of Agric. Res., New Delhi, pp. 167-174.

Sathya, M. and Jayamani, P. 2011. Heterosis and combining ability studies in greengram. J. of Food Legumes 24(4): 282-287. Shanthi Priya, M., Reddy, K H. P Reddy D. M., and Rupesh Kumar Reddy., 2012. Combining ability studies in greengram. (Vigna radiate (L.) 
Wilczek). Legume Res., 31(1): 36-39.

Singh M., 2005. Study of combining ability for physiological traits in urdbean (Vigna mungo (L.) Hepper). Legume Res., 28(2):107-110.

Singh, B. B. and Dikshit, H. K. 2003. Combining ability studies for yield and architectural traits in mungbean. (Vigna radiate (L.) Wilczek) Indian J. Genet., 63(4): 351-352.

Surashe, S.M., D.K. Patil and V.K. Gite.
2017. Combining Ability for Yield and Yield Attributes Characters in Greengram (Vigna radiate L. Wilczek) Int.J.Curr.Microbiol.App.Sci (2017) 6(11): 3552-3558.

Yadav, P. S. and Lavanya, G. R. 2011. Estimation of combining ability effect in mungbean (Vigna radiate (L.) Wilczek) crosses. Madras Agric. J. 98 (7-9): 213-215.

\section{How to cite this article:}

Kakde, S.S., A.B. Gawate and Mandge, S.V. 2019. Estimation of Combining Ability Effect in Mungbean (Vigna radiata (L.) Wilczek). Int.J.Curr.Microbiol.App.Sci. 8(02): 1668-1674. doi: https://doi.org/10.20546/ijcmas.2019.802.196 